\section{Meeting the complex challenge of health and social care provision for rapidly-ageing populations: introducing the concept of "avoidable displacement from home"}

\section{O enfrentamento do desafio complexo da prestação de serviços de saúde e sociais para populações com envelhecimento rápido: a introdução do conceito de "deslocamento residencial evitável"}

Resolver el complejo desafío para la salud y atención social en poblaciones que envejecen rápidamente: introduciendo el concepto de "desplazamiento evitable desde el hogar"
Peter Lloyd-Sherlock 1

Jenny Billings 2

Janaina de Souza Aredes 3

João Bastos Freire Neto 4

Ana Amélia Camarano 5

João Macedo Coelho Filho 6

Josélia Oliveira Araújo Firmo 3

Alexandre Kalache 7

James Macinko 8

Lucas Sempé 1

Karla Cristina Giacomin 9

doi: 10.1590/0102-311X00162819

\begin{abstract}
The increasing numbers of people at very old ages pose specific policy challenges for health and social care and highlight the need to rethink established models of service provision. The main objective of this paper is to introduce the concept of "avoidable displacement from home" (ADH). The study argues that ADH builds on and adds value to existing concepts, offering a holistic, person-centered framework for integrated health and social care provision for older people. It also demonstrates that this framework can be applied across different levels, ranging from macro policymaking to organizational and individual decision-making. The paper pays attention to the Brazilian context but argues that $A D H$ is a universally applicable concept.
\end{abstract}

Aged; Intersectoral Collaboration; Comprehensive Health Care; Hospitalization

\section{Correspondence}

J. S. Aredes

Instituto René Rachou, Fundação Oswaldo Cruz.

Av. Augusto de Lima 1715, Belo Horizonte, MG 30190-002, Brasil.

janainaaredes@gmail.com

1 University of East Anglia, Norwich, U.K

2 University of Kent, Kent, U.K.

3 Instituto René Rachou, Fundação Oswaldo Cruz, Belo Horizonte, Brasil.

4 Secretaria Municipal de Saúde de Fortaleza, Fortaleza, Brasil.

5 Instituto de Pesquisa Econômica Aplicada, Rio de Janeiro, Brasil.

6 Faculdade de Medicina, Universidade Federal do Ceará, Fortaleza, Brasil.

7 Centro Internacional de Longevidade, Rio de Janeiro, Brasil.

8 University of California, Los Angeles, U.S.A.

${ }^{9}$ Secretaria Municipal de Saúde de Belo Horizonte, Belo

Horizonte, Brasil. 


\section{Introduction}

Low and middle-income countries are experiencing accelerated population ageing, with rapid increases in the numbers of people at very old ages. Developing well-integrated health and social care systems represents a daunting challenge for all countries. In high-income countries - where separate systems of health and social care have evolved independently over several decades, belatedly reengineering them into a single, integrated service - it has proved to be much more easily said than done 1 . Emerging economies have an opportunity to avoid these policy mistakes at an earlier stage of service development. To do so will require fundamental changes to established paradigms of policymaking, as well as to models of service provision and professional behavior. This paper discusses these challenges and proposes a new conceptual framework to support policy responses.

\section{An ageing world}

According to data taken from the UN Department of Economic and Social Affairs about population dynamics by $2015,67 \%$ of all people aged over 70 lived in less developed regions, and this figure will rise to $76 \%$ in 20502 . Over the same period, the share of Brazilian population aged 70 and over will approximately treble from 5.1 to $16.4 \%$ (Table 1). Yet, research and policy discussions about the needs of very old people remain focussed on more-developed regions 3 .

\section{Table 1}

Current and projected population aged 70 and above.

\begin{tabular}{|c|c|c|c|}
\hline Year & More developed regions & Less developed regions & Brazil \\
\hline \multicolumn{4}{|l|}{2015} \\
\hline Population aged 70+ & 153,319 & 242,073 & 10,423 \\
\hline$\%$ of total population & 12.2 & 3.9 & 5.1 \\
\hline \multicolumn{4}{|l|}{2020} \\
\hline Population aged 70+ & 172,539 & 287,453 & 12,983 \\
\hline$\%$ of total population & 13.6 & 4.4 & 6.1 \\
\hline \multicolumn{4}{|l|}{2025} \\
\hline Population aged 70+ & 194,329 & 362,510 & 16,320 \\
\hline$\%$ of total population & 15.2 & 5.3 & 7.4 \\
\hline \multicolumn{4}{|l|}{2030} \\
\hline Population aged 70+ & 216,356 & 439,839 & 20,225 \\
\hline$\%$ of total population & 16.8 & 6.1 & 9.0 \\
\hline \multicolumn{4}{|l|}{2035} \\
\hline Population aged 70+ & 236,686 & 535,598 & 24,796 \\
\hline$\%$ of total population & 18.3 & 7.0 & 10.8 \\
\hline \multicolumn{4}{|l|}{2040} \\
\hline Population aged 70+ & 250,225 & 644,804 & 29,213 \\
\hline$\%$ of total population & 19.3 & 8.1 & 12.6 \\
\hline \multicolumn{4}{|l|}{2045} \\
\hline Population aged 70+ & 260,902 & 745,306 & 33,433 \\
\hline$\%$ of total population & 20.1 & 9.1 & 14.4 \\
\hline \multicolumn{4}{|l|}{2050} \\
\hline Population aged 70+ & 267,911 & 827,848 & 38,244 \\
\hline$\%$ of total population & 20.6 & 9.8 & 16.4 \\
\hline
\end{tabular}

Source: based on the World Population Prospects data 2. 
The specific policy challenges caused by the increasing numbers of people at very old ages are worth discussing. Disorders and functional decline are more prevalent for people aged 70 and over than for people at younger ages. Table 2 compares data on the functional status of older adults from a Brazilian national survey ${ }^{4}$ to surveys in Mexico ${ }^{5}$ and the USA 6 . These surveys belong to the Health Retirement Survey (HRS) family and use the same criteria to define disability 7 , which permits crossnational comparisons. The proportion of older people with at least one functional limitation rises sharply with age, and in Mexico it has increased significantly over time for all age groups (longitudinal data are not yet available for Brazil). A combination of rapid population ageing and high levels of functional impairment are generating an escalation in demand for social care and geriatric health services 4,5,6. The intensity of care needs is particularly high for conditions such as dementia. It has been estimated that the number of people with this condition in Latin America will rise from 7.8 million in 2013 to over 27 million by 2050 . However, dementia is not the only condition that leads to complex and intensive care needs in later life; frailty, multi-morbidity and other specific conditions are also associated with severe levels of care dependency. For example, the Brazilian National Health Survey (PNS, in Portuguese) estimated that there were 568,000 people with severe disabilities due to stroke alone in 20139.

Rapidly escalating demand for long-term care and the limited capacity of families to meet this need call for robust policy responses by governments. In countries like Brazil, demographic trends, changes to family structures and increased female participation in paid work reduce the supply of potential family carers 10 . The experiences of high-income countries demonstrate a need to develop coordinated, inter-sectoral responses across different agencies 1,11 . There is growing evidence that caring for older family members is highly stressful, physically, financially and emotionally draining 12,13 . This does not mean, however, that formal service provision should be viewed as a direct substitute for family care. Instead, the two should be considered complementary parts of an integrated system of health and social care for older people 11. The large variations in age-specific functional status shown in Table 2 in part reflect the potential for health interventions to limit the onset of functional decline and hence demand for long-term care 10. Similarly, appropriate long-term care provision can substantially reduce demand for mainstream health services, which are often more expensive.

\section{Avoidable displacement from home}

Avoidable displacement from home $(\mathrm{ADH})$ can be understood as a failure to deliver care that enables older people to choose to remain in their homes for as long as possible when this is in their best interest. It offers a comprehensive and holistic framework to treat health and social care as a single system, by examining relationships between different care settings. It combines consideration of individual preferences and personal agency with a health systems perspective. In this way, ADH encompasses

Table 2

Percentage of older people over reporting at least one functional limitation (ability to eat, get dressed, transfer in and out of bed, use the toilet, and bathe/shower).

\begin{tabular}{|c|c|c|c|c|c|c|c|c|c|c|}
\hline \multirow[t]{2}{*}{ Country (Survey) } & \multicolumn{4}{|c|}{ Men } & \multicolumn{4}{|c|}{ Women } & \multicolumn{2}{|c|}{ Total } \\
\hline & $60-69$ & $70-79$ & $80+$ & p-value & $60-69$ & $70-79$ & $80+$ & p-value & Aged 60+ & $\mathbf{N}$ \\
\hline Brazil (ELSI 2015/2016) & 13.5 & 15.7 & 32.9 & $<0.0001$ & 14.8 & 22.3 & 37.7 & $<0.0001$ & 18.7 & 5,432 \\
\hline Mexico * (MHAS 2001) & 6.6 & 13.2 & 34.3 & $<0.0001$ & 10.4 & 15.5 & 42.2 & $<0.0001$ & 14.6 & 6,692 \\
\hline Mexico (MHAS 2012) & 10.3 & 20.1 & 35.3 & $<0.0001$ & 17.5 & 28.3 & 52.0 & $<0.0001$ & 21.2 & 8,974 \\
\hline USA (HRS 2012) & 13.8 & 18.1 & 31.9 & $<0.0001$ & 17.0 & 20.0 & 41.4 & $<0.0001$ & 22.1 & 3,889 \\
\hline
\end{tabular}

Sources: Brazil - Brazilian Longitudinal Study of Ageing (ELSI), wave 1 (2015/2016) 4; Mexico - Mexican Health and Aging Study (MHAS), waves 1 (2001) and 3 (2012) 5; USA - Health and Retirement Study (HRS), wave 13 (2012) 6.

* Variation of prevalence of disability in at least one activity of daily living over time in Mexico: $p$-value $<0.0001$ in the $95 \%$ confidence interval. 
and adds value to several established concepts, including person-centered models of geriatric care, integrated care, ageing in place and continuity of care 14,15,16.

$\mathrm{ADH}$ results from relationships between different care settings considered problematic, either from a health systems perspective and/or in terms of older people's preferences. These settings are where the older person currently resides, either on a long-term or (in the case of most hospitalizations) short-term basis. As such, they include residential care homes, as well as the home and inpatient hospital settings (Figure 1). These relationships may be considered problematic when they promote the following outcomes:

- (Re)admissions to hospitals that could be reasonably avoided. Including admissions for inappropriate clinical reasons, conditions potentially amenable to treatment in non-inpatient settings, and admissions for preventable conditions (such as acute health episodes resulting from inadequate self-care or falls).

- Unnecessarily long hospital stays, due to delayed discharge. Due to inappropriate discharge protocols or a lack of suitable support for patients outside the hospital setting.

- Unnecessary admissions into care homes. Admissions of older people whose needs could be adequately met within domiciliary settings.

\section{Policy relevance of ADH}

ADHs contribute to growing pressures on health service funding in different ways. They include hospitalizations for ambulatory care-sensitive conditions (ACSC), which could have been avoided if

\section{Figure 1}

Simple schema of the concept of avoidable displacement from home (ADH).

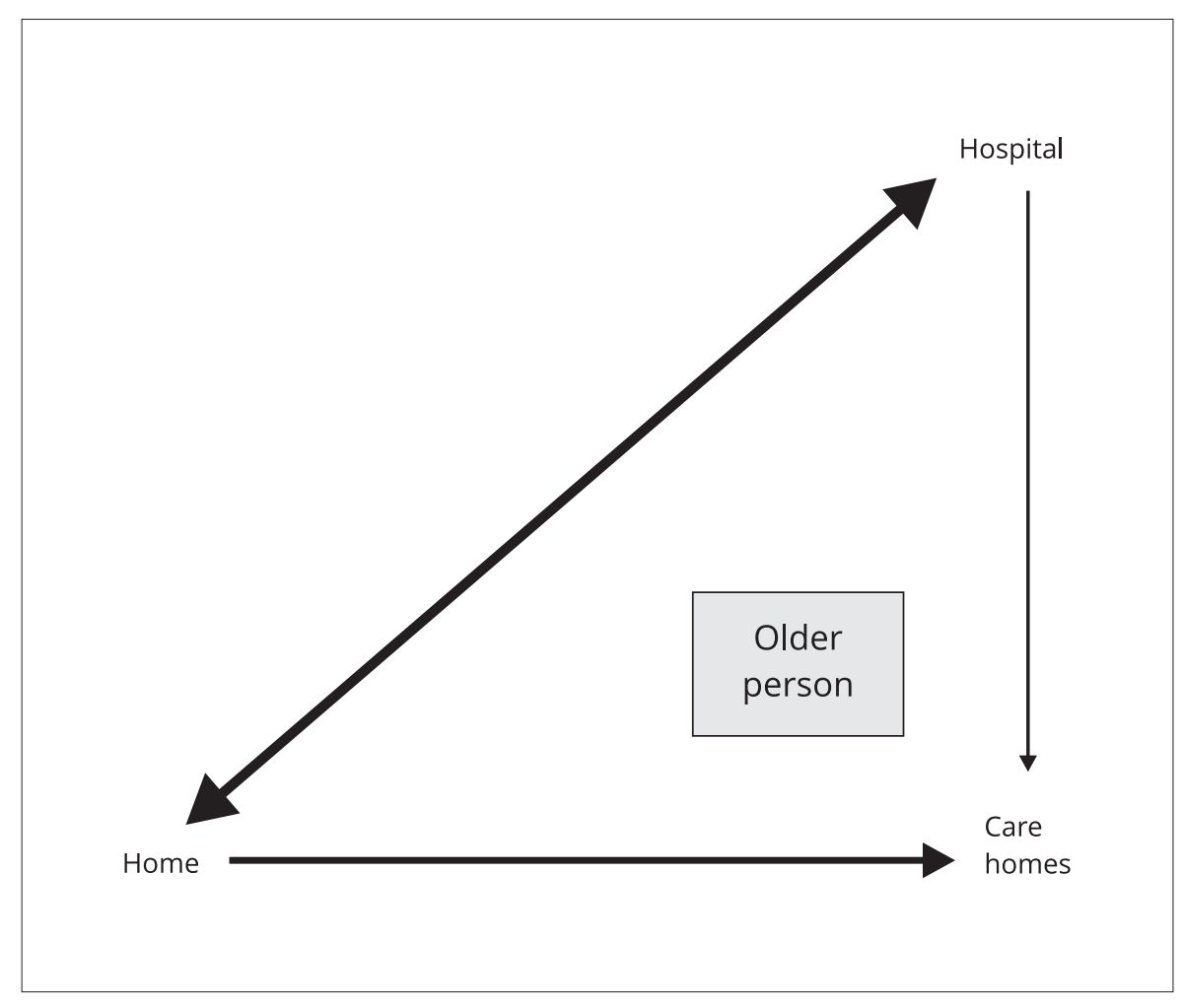


suitable primary health care services had been available to the patient 17 . Older people represented $15 \%$ of the Brazilian adult population in 2012, but accounted for almost a third of all hospital admissions and more than half of intensive care admissions in the public health system between 2009 and 2015. Additionally, older inpatients account for $39 \%$ of the total adult inpatient budget of public hospitals 18 . It has been calculated that $31 \%$ of inpatient hospital spending on people aged 60 and over in the Brazilian Unified National Health System (SUS, in Portuguese) between 2000 and 2013 was for conditions suited for ambulatory treatment. This amounted to around USD 275 million of hospital spending in 201319 .

ADHs also include conditions appropriate for inpatient care, but that could have been easily prevented by suitable outpatient health and social care. Combining inappropriate and preventable hospitalization, studies of hospital admissions of older people in the UK estimate that between 20 and $32 \%$ of such admissions could be defined as "inappropriate" 20,21,22.

A third element of ADH is unnecessarily long hospital stays, when inpatients deemed medically fit for discharge continue to occupy a hospital bed for nonclinical reasons. The mean cost of a single case of delayed hospital discharge has been estimated at USD 7,020 by a systematic international review 23 .

As well as the wasteful use of resources, there are many other benefits to minimising ADHs.

First, older people face particular risks from unneeded hospitalization, such as hospital-acquired infections 24. Data for Brazil show that rates of such infections were 13.3\% for inpatients aged 60 and over, compared to $7.2 \%$ for the total inpatient population, and that these infections were associated with longer hospital stays 25. Between 2009 and 2015, the proportion of inpatients aged 60 or more who died in hospital rose from 9.8 to $11.2 \% 18$.

Second, where hospital inpatient capacity and beds in residential care homes are limited, ADHs reduce access to appropriate care for those people who really need it. This is especially problematic when the supply of beds is very limited, as is the case in Brazil, where the number of hospital beds per 1,000 inhabitants in 2014 was 2.11 compared to 8.13 and 13.17 in Germany and Japan, respectively 26,27.

Finally, older people usually express a strong preference to remain in their own homes and this is associated with enhanced quality of life, and in some cases, better health 11. In Latin America and Brazil, in part, this preference may reflect evidence that the quality of care in many care homes and inpatient settings leaves much to be desired 28 .

As well as addressing these issues individually, $\mathrm{ADH}$ encourages policymakers to go beyond an exclusive focus on health system efficiency and quality management, such as improving primary health care to reduce hospitalizations. This narrow view neglects the wider perspective of place-based care (such as poor or fragmented service provision) or the person-centered experiences, needs and wishes of older people and their carer 29,30. One specific gap in current approaches is the relationships between care homes and other care settings. Just as is the case with hospital admissions, this can include avoidable and unnecessary admissions into care homes when older people have limited care dependency or when their needs might be met within domiciliary settings, were the appropriate services may be available to support and complement family care 10 .

\section{Comparing preliminary ADH components across different contexts}

Patterns of $\mathrm{ADH}$ components vary between countries. Compared to high income countries, fewer old people live in residential care homes in less developed countries 11. In Brazil, less than 1\% of older people were living in care homes in 2018 , compared to $4.7 \%$ of people aged 65 and over in the UK in 2016 27,31. Conversely, average lengths of hospital stays in less developed countries tend to be high by international standards. This indicates that a relatively high proportion of hospital stays in countries like Brazil may be for conditions better suited to care homes or domiciliary settings. A survey of hospital inpatients aged 60 and over in Rio de Janeiro between 2001 and 2007 found 2,260 had been there for over a year 32. A survey of 11 public hospitals in Chile in 2014 categorized 36\% of stays of over a month as "social hospitalizations" (patients no longer in need of inpatient care, but who could not be discharged due to the unavailability of care at home) 33 .

Unnecessarily protracted hospital stays do not mean countries should seek to directly substitute social hospitalization with residential care facilities. In many cases, care homes also represent a 
sub-optimal form of provision, in terms of both cost-effectiveness and the quality of service they offer 11. For example, in Argentina, a significant number of residential care facility residents have neither moderate nor high levels of care dependency. Older people rarely express a preference for moving to a care home and admissions are often coercive, sometimes constituting an unjustifiable deprivation of liberty 34,35 .

Furthermore, the extent to which the home represents the best environment for older people varies between settings. For example, in poor urban neighborhoods, substandard housing conditions and lack of safe pavements, among many other things, reduces their suitability for frail older people 36 . At the same time, the capacity of families to provide care varies according to the availability, disposition and ability of relatives to perform this role. Unpaid family carers, almost always women, often lack basic knowledge about older people's care and are exposed to high levels of stress. A survey of 52 family carers for people with dementia in Colombia found that $55.8 \%$ had been performing this demanding role for over three years and most had little knowledge of the condition of their cared for older relative 37 .

Figure 2 presents a stylized summary of how different processes can generate ADH across settings and at different levels. In high-income countries, a lack of family support is a major cause of delayed discharge from hospital 38. It is sometimes claimed that family support is more abundant in countries like Brazil, but the 2013 PNS found that the majority of Brazilians aged 60 and over with care needs received no support from either a family member or another person 10 . There is evidence that gaps in family support and social care contribute significantly to ADH in Brazil 32,39. Additionally, high-income country experiences show that inadequate local primary health services make a major contribution to $\mathrm{ADH}$, as does poor coordination between services and limited coverage of health insurance 40,41. These effects are likely to be significant in countries like Brazil, where local service infrastructure is limited and tends to focus on the needs of younger people. In 2013, 31.3\% of Brazilians aged 60 and over were not enrolled in the Family Health Strategy 42. Municipal data for poor neighborhoods of Belo Horizonte (Minas Gerais State) show that older people living further than 500 metres away from a health unit had significantly lower use rates than those living closer. Shortage of locally available outpatient services increases rates of emergency department utilization and this, in turn, is strongly associated with admissions for avoidable or preventable conditions 43 . Similarly, poor health management in long-term care facilities, coupled with limited coordination with local health services further contribute to unneeded hospitalizations. A study in Japan found that most hospita admissions of nursing home residents were potentially avoidable 44 .

\section{Reducing ADH}

Significant cost benefits can be achieved by reducing ADH. For example, in the UK, the average length of inpatient stay for people aged 70 to 74 fell from 9.6 to 8 days between 2007 and 2016, without a comparable increase in the numbers of people in residential care 45 . The USA achieved a $20 \%$ reduction in average length of hospital stays between 1993 and 2009, which is equivalent to 0.1 days per older person 46 .

Table 3 shows estimated cost savings for an annual reduction of 0.1 days of hospital inpatient stays for people aged 60 and over as well as 70 and over in 2015 and 2030 47,48. The calculation multiplies the cost of a single inpatient day (using 2005 World Health Organization - WHO - data on public district hospital costs) by the population in each age group for the corresponding year and then divides it by ten. In Brazil, the estimated savings for the population aged 60 and over would be USD 197 million in 2015 and USD 342 million in 2030. The corresponding savings only for the population aged 70 and over would be USD 84 million and USD 162 million. While this is a very approximative exercise, it provides an indication of the scale of potential savings. These are likely to be conservative estimates done by the authors based on the WHO data 47, as: (i) district hospitals stays are considerably cheaper than in teaching hospitals; and (ii) the costs of hospital days in 2015 and 2030 will be higher than in 2005.

However, in high-income countries, there are growing concerns about potentially detrimental effects on older people of reducing hospital stays "at all costs" 49 . How can hospital stays be reduced 
Table 3

Estimated cost savings of reducing annual inpatient hospital stays by 0.1 days per person aged 60 and over and 70 and over.

\begin{tabular}{|c|c|c|c|c|c|}
\hline Country & $\begin{array}{l}\text { District hospitals } \\
\text { cost per day per } \\
\text { person (USD/2005) }\end{array}$ & $\begin{array}{l}\text { Total cost of } 0.1 \\
\text { days in district } \\
\text { hospital multiplied } \\
\text { by population } \\
\text { aged } 60+(\text { million } \\
\text { USD/2015) }\end{array}$ & $\begin{array}{l}\text { Total cost of } 0.1 \\
\text { days in district } \\
\text { hospital multiplied } \\
\text { by population } \\
\text { aged } 70+(\text { million } \\
\text { USD/2015) }\end{array}$ & $\begin{array}{l}\text { Total cost of } 0.1 \\
\text { days in district } \\
\text { hospital multiplied } \\
\text { by population } \\
\text { aged } 60+(\text { million } \\
\text { USD/2030) }\end{array}$ & $\begin{array}{l}\text { Total cost of } 0.1 \\
\text { days in district } \\
\text { hospital multiplied } \\
\text { by population } \\
\text { aged } 70+(\text { million } \\
\text { USD/2030) }\end{array}$ \\
\hline Brazil & 80.60 & 197 & 84 & 342 & 162 \\
\hline Mexico & 88.04 & 106 & 47 & 189 & 82 \\
\hline USA & 628.43 & 4,143 & 1,966 & 5,666 & 3,222 \\
\hline
\end{tabular}

Sources: UN Population Division (median variant projection for 2030) 47; World Health Organization (2010) 48.

without either shifting the burden to care homes or family carers, or harming the wellbeing of older people? The experiences of high-income countries indicate this cannot be achieved through a single or simple set of interventions. Most studies emphasize a need for packages of community-level interventions based on integrated health and social care 50 . This has proved to be a challenging agenda: many countries are belatedly attempting to integrate systems of health and social care which were allowed to develop separately over time ${ }^{11}$. Other countries may be able to learn from these past mistakes, by applying more comprehensive $\mathrm{ADH}$ strategies.

In countries like Brazil, almost no family carers of older people receive meaningful support in performing this role. Yet, the experience of high-income countries demonstrates the potential effectiveness of a wide range of interventions. For example, in Finland, long-term care policy places a large emphasis on respite services for people who care for older relatives. This constitutes a wider policy goal to ensure that at least $90 \%$ of people aged 75 or more can remain at home 51 .

There is a need for the careful coordination of complementary interventions across a wide range of agencies and stakeholders, but evidence on the effectiveness of many interventions remains very limited for high-income settings 52 . Even in cases where evidence exists, it should not be assumed that outcomes will be the same if these interventions are directly replicated in less-developed settings. There is an urgent need to build knowledge of what works in countries like Brazil, both in terms of specific interventions to support care at home, as well as how they can be effectively combined into a wider strategy of reducing ADH.

Some countries in Latin America have started to develop interventions to address specific aspects of ADH. However, these are generally quite limited in terms of scope and resources, and they usually do not address ADH as a whole 33 . National level programs are being developed alongside policy experimentation at local government level 53 . There is an urgent need to develop comparative evaluations of these different interventions and to share experiences.

\section{Conclusion}

This paper has introduced the concept of "avoidable displacement from home" and demonstrated its potential application in Brazil and other countries. The development of the concept is at an early stage and will require more detailed elaboration, as well as validation, by policymakers.

At first sight, the concept of $\mathrm{ADH}$ has several potential advantages. First, it recognizes the inseparability of health and social care and the need to view them as part of a single system, not as two conjoined ones. Second, it places equal emphasis on system efficiency and the needs and preferences of older people. Existing concepts fail to provide a holistic, person-centered and place-based understanding of how being "displaced" from home is experienced by older people and their carers. Third, $\mathrm{ADH}$ combines an element of conceptual simplicity (as illustrated in Figure 1) with a more elaborate framework to guide the analysis of more complex underlying processes (such as Figure 2). Finally, 
Figure 2

Summary of the different processes that generate avoidable displacement from home (ADH).

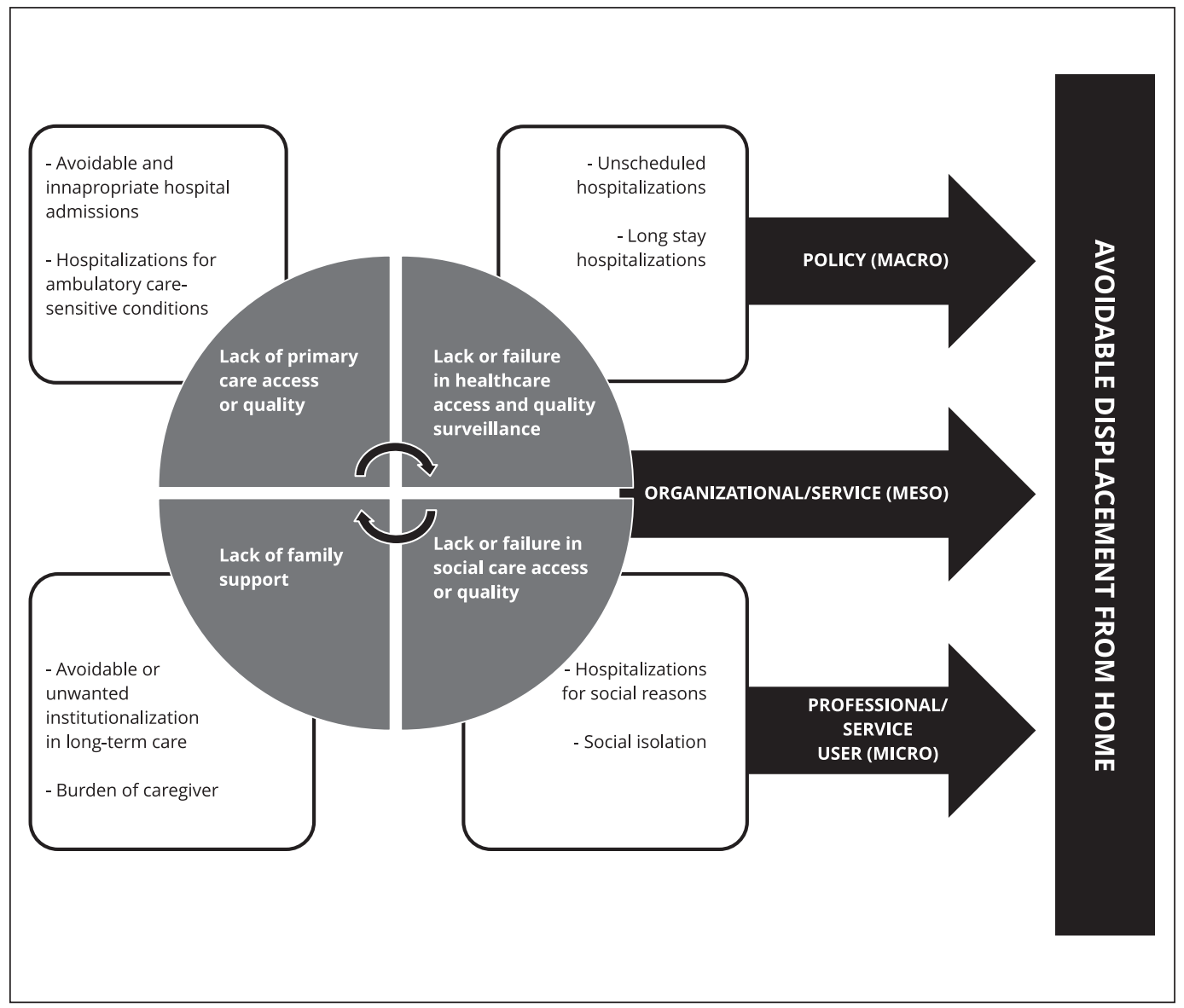

$\mathrm{ADH}$ contemplates rapidly emerging policy concerns in countries like Brazil and may serve as a bridge between research and policymaking.

Despite its conceptual simplicity, the application of ADH to real life scenarios is likely to be challenging. Establishing what may or may not constitute an avoidable or inappropriate displacement from home will depend on personal expertise and an element of subjective judgement. ADH should not be interpreted as a binary phenomenon, but as a spectrum of judgements, ranging from more obvious and egregious cases to more marginal ones. This is likely to be context-specific and judgements may vary within and across different professions. For example, despite the fact that there are some ACSC used for classifying hospitalizations as ACSC, using the International Classification of Diseases (ICD-10) codes, and following the definitions of Alfradique et al. 54 for Brazil, it remains the only country in Latin America that has made a systematic effort to adapt the ACSC lists from the USA, Canada and Spain to its own circumstances. However, it is important to note that until now there is no international consensus on how to best compose ACSC lists 55. We could argue that age-neutral ACSC lists are not sensitive to the needs of very old people (for whom hospitalization due to a given condition may be more appropriate than for people of other ages). This demonstrates the danger of reducing $\mathrm{ADH}$ to a simple set of criteria. Rather than over-simplify, it may be instructive to explore different meanings and interpretations of $\mathrm{ADH}$ across settings and stakeholders, as part of a concept 
validation process. Identifying these disagreements may reveal valuable policy lessons to enhance service integration in a meaningful and sustainable way and support person-centered care.

A final word of caution. ADH should not be used to justify policies and strategies that assume "home is always best" for older people, thus delegating all responsibility to families and minimizing state responsibility. Such an approach ignores the potential unsuitability of home environments for some older people and the limitations of family care. Also, it places an unjust burden on a growing army of mainly female family carers. Additionally, seeking to reduce unnecessary admissions into care homes does not equate to the view that these admissions are always a bad option. Across Latin America, social attitudes tend to view social care as a private family concern and the use of formal services is often stigmatized. Properly interpreted, however, ADH should challenge these misconceptions, rather than reinforce them. Instead of seeking to reduce admissions at all costs, ADH emphasizes place-based care that is appropriate to the needs and preferences of the older person.

Regardless of policy, rapid increases in numbers of frail, care-dependent older people will generate rising demand for both formal social care and related health services. Existing models of health and social care are already unfit for purpose. Effective resource allocation can only be achieved through strong partnerships, where families are provided support by integrated health and social care at the community level, and where the preferences of older people and their carers are properly acknowledged.

\section{Contributors}

P. Lloyd-Sherlock contributed to the study design, data analysis and interpretation, writing of the paper and critical review. J. Billings, J. S. Aredes, and K. C. Giacomin contributed to the data analysis and interpretation, writing of the paper and critical review. J. B. Freire Neto, A. A. Camarano, J. M. Coelho Filho, J. O. A. Firmo, A. Kalache, J. Macinko, and L. Sempé made specific analytical contributions of significant value to the work. All authors approved the final version of the manuscript, being responsible for all aspects of the work.

\section{Additional informations}

ORCID: Peter Lloyd-Sherlock (0000-0002-13670703); Jenny Billings (0000-0002-5660-9478); Janaína de Souza Aredes (0000-0002-4147-2405); João Bastos Freire Neto (0000-0002-4557-0029); Ana Amélia Camarano (0000-0003-4905-0490); João Macedo Coelho Filho (0000-0001-91435090); Josélia Oliveira Araújo Firmo (0000-00023264-9627); Alexandre Kalache (0000-0002-32030568); James Macinko (0000-0001-8055-5441); Lucas Sempé (0000-0002-0978-6455); Karla Cristina Giacomin (0000-0002-9510-6953).

\section{Acknowledgments}

This project was supported by the UK Medical Research Council (number MR/R024219/1) and the Minas Gerais State Research Foundation (FAPEMIG; APQ-01141-18). The authors acknowledge the contribution of Carlos Díaz-Venegas to the data analysis in Table 2.

\section{References}

1. Charles A, Wenzel L, Kershaw M, Ham C, Walsh N. A year of integrated care systems: reviewing the journey so far. London: The King's Fund; 2018.

2. Department of Economic and Social Affairs, United Nations. World population prospects: the 2017 revision. Volume I: comprehensive tables. https://population.un.org/wpp/Data Sources/ (accessed on 10/Jun/2019).

3. Lloyd-Sherlock P. Beyond neglect: long-term care research in low and middle income countries. Int J Gerontol 2014; 8:66-9.

4. Oswaldo Cruz Foundation. Brazilian Longitudinal Study of Aging. http://elsi.cpqrr.fiocruz. br/en/ (accessed on 10/Jun/2019).

5. National Institute on Aging, National Institutes of Health. Mexican Health and Aging Study. http://www.mhasweb.org/ (accessed on 10/Jun/2019).

6. National Institute on Aging. Health and Retirement Study. http://hrsonline.isr.umich.edu/ index.php?p=avail (accessed on 08/Jun/2019).

7. Lima-Costa MF, Andrade FB, Souza PRB, Neri AL, Duarte YAO, Castro-Costa E, et al. The Brazilian Longitudinal Study of Aging (ELSIBrazil): objectives and design. Am J Epidemiol 2018; 187:1345-53.

8. Custodio N, Wheelock A, Thumala D, Slachevsky A. Dementia in Latin America: epidemiological evidence and implications for public policy. Front Aging Neurosci 2017; 9:221.

9. Bensenor IM, Goulart AC, Szwarcwald CL, Vieira ML, Malta DC, Lotufo PA. Prevalence of stroke and associated disability in Brazil: National Health Survey - 2013. Arq Neuropsiquiatr 2015; 73:746-50. 
10. Giacomin K, Duarte Y, Camarano A, Nunes D, Fernandes D. Care and functional disabilities in daily activities - ELSI-Brazil. Rev Saúde Pública 2018; 52 Suppl 2:9s.

11. World Health Organization. World report on ageing and health. Geneva: World Health Organization; 2015.

12. Choo W, Low W-Y, Karina R, Ebenezer E, Prince MJ. Social support and burden among caregivers of patients with dementia in Malaysia. Asia Pac J Public Health 2003; 15:23-9.

13. Lloyd-Sherlock P, Mayston R, Acosta A, Gallardo S, Guerra M, Sosa AL, et al. Allocating family responsibilities for dependent older people in Mexico and Peru. J Dev Stud 2018; 54:682-701.

14. McCormack B. A conceptual framework for person-centred practice with older people. Int J Nurs Pract 2003; 9:202-9.

15. Cornwell J, Levenson R, Sonola L, Poteliakhoff E. Continuity of care for older hospital patients a call for action. London: The King's Fund; 2012.

16. Snowdon A, Schnarr K, Alesssi C. "It's all about me": the personalization of health systems. London: Ivey International Centre for Health Innovation, Ivey Business School, Western University; 2014.

17. Billings J, Zeitel L, Lukomnik J, Carey TS, Blank AE, Newman L. Impact of socioeconomic status on hospital use in New York City. Health Aff (Millwood) 1993; 12:162-73.

18. Dias RD, Barros JV. Burden of hospitalisation among older people in the Brazilian public health system: a big data analysis from 2009 to 2015. J Epidemiol Community Health 2019; 73:537-43.

19. Souza DK, Peixoto SV. Estudo descritivo da evolução dos gastos com internações hospitalares por condições sensíveis à atenção primária no Brasil, 2000-2013. Epidemiol Serv Saúde 2017; 26:285-94.

20. Leah V, Adams J. Assessment of older adults in the emergency department. Nurs Stand 2010; 24:42-5.

21. Mytton OT, Oliver D, Mirza N, Lippett J, Chatterjee A, Ramcharitar K, et al. Avoidable acute hospital admissions in older people. British Journal of Healthcare Management 2012; 18:597-603.

22. McDonagh MS, Smith DH, Goddard M. Measuring appropriate use of acute beds. A systematic review of methods and results. Health Policy 2000; 53:157-84.

23. Landeiro F, Roberts K, Gray AMI, Leal J. Delayed hospital discharges of older patients: a systematic review on prevalence and costs. Gerontologist 2019; 59:e86-97.

24. Rothan-Tondeur M, Meaume S, Girard L, Weill-Engerer S, Lancien E, Abdelmalak S, et al. Risk factors for nosocomial pneumonia in a geriatric hospital: a control-case one-center study. J Am Geriatr Soc 2003; 51:997-1001.
25. Couto RC, Pedrosa TMG, Roberto BAD, Daibert PB. Anuário da segurança assitencia hospitalar no Brasil. Belo Horizonte: Instituto de Estudos de Saúde Suplementar; 2017.

26. Economic Commission for Latin America and the Caribbean. Statistical yearbook for Latin America and the Caribbean 2018. Santiago: Economic Commission for Latin America and the Caribbean; 2019.

27. Organisation for Economic Co-operation and Development. OECD.Stat. https://stats.oecd. org/index.aspx?queryid $=30183$ (accessed on 10/Jun/2019)

28. Souza DMST, Santos VLCG. Factores de riesgo para el desarrollo de úlceras por presión en ancianos. Rev Latinoam Enferm 2007; 15:958-64.

29. Glasby J, Littlechild R, Le Mesurier N, Thwaites R. Who knows best? Older people's and practitioner contributions to understanding and preventing avoidable hospital admissions. Health Econ Policy Law 2019; [Epub ahead of print].

30. Sixsmith J, Sixsmith A, Fänge AM, Naumann D, Kucsera C, Tomsone S, et al. Healthy ageing and home: the perspectives of very old people in five European countries. Soc Sci Med 2014; 106:1-9.

31. Oliveira Duarte Y, Wada Wataname H, Lebrão M. Estudo das condições socioedemográficas e epidemiológicas dos idosos residentes em instituições de longa permanência para idosos registradas no Censo SUAS (Sistema Único de Assistentência Social). São Paulo: Faculdade de Saúde Pública, Universidade de São Paulo; 2018.

32. Romero DE, Marques A, Barbosa AC, Sabino R. Internações de idosos por cuidados prolongados em hospitais do SUS no Rio de Janeiro: uma análise de suas características e da fragilidade das redes sociais de cuidado. In: Camarano A, editor. Cuidados de longa duração para a população idosa: um novo risco social a ser assumido? Rio de Janeiro: Instituto de Pesquisa Econômica Aplicada; 2010. p. 249-78.

33. Ministerio de Desarrollo Social. Camas socio sanitarias. Informe de descripción de programas sociales. Santiago: Ministerio de Desarrollo Social; 2015.

34. Lloyd-Sherlock P, Penhale B, Redondo N. The admission of older people into residential care homes in Argentina: coercion and human rights abuse. Gerontologist 2018; 59:610-8.

35. Dias IG. A institucionalização asilar na percepção do idoso e de sua família: o estudo do "lar dos velhinhos”. Viçosa: Universidade Federal de Viçosa; 2007.

36. Alcântara AO, Camarano AA, Giacomin KC. Política nacional do idoso: velhas e novas questões. Rio de Janeiro: Instituto de Pesquisa Econômica Aplicada; 2016. 
37. Cerquera Córdoba AM, Pabón Poches DK, Uribe Báez DM. Nivel de depresión experimentada por una muestra de cuidadores informales de pacientes con demencia tipo Alzheimer. Psicol Caribe 2012; 29:360-84.

38. Landeiro F, Leal J, Gray AM. The impact of social isolation on delayed hospital discharges of older hip fracture patients and associated costs. Osteoporos Int 2016; 27:737-45.

39. Melo-Silva A, Mambrini J, Souza-Junior P, Bof de Andrade F, Lima-Costa M. Hospitalizations among older adults: results from ELSI-Brazil. Rev Saúde Pública 2018; 52 Suppl 2:3s.

40. Department of Health and Social Care. Caring for our future: reforming care and support. London: Department of Health and Social Care; 2012.

41. Muenchberger H, Kendall E. Predictors of preventable hospitalization in chronic disease: priorities for change. J Public Health Policy 2010; 31:150-63.

42. Boccolini CS, Souza Junior PRB. Inequities in healthcare utilization: results of the Brazilian National Health Survey, 2013. Int J Equity Health 2016; 15:150.

43. D'Souza S, Guptha S. Preventing admission of older people to hospital. BMJ 2013; 346:f3186.

44. Jeon B, Tamiya N, Yoshie S, Iijima K, Ishizaki T. Potentially avoidable hospitalizations, nonpotentially avoidable hospitalizations and inhospital deaths among residents of long-term care facilities. Geriatr Gerontol Int 2018; 18:1272-9.

45. Eurostat. Hospital discharges and length of stay statistics. http://appsso.eurostat.ec. europa.eu/nui/submitViewTableAction.do (accessed on 09/Jun/2019).

46. Wier LM, Pfuntner A, Maeda J, Stranges E, Ryan K, Jagadish P, et al. HCUP facts and figures: statistics on hospital-based care in the United States, 2009. Rockville: Agency for Healthcare Research and Quality; 2011.
47. Department of Economic and Social Affairs, United Nations. Population data. https:// population.un.org/wpp/Download/Standard/ Population/ (accessed on 12/Jun/2019).

48. World Health Organization. CHOosing Interventions that are Cost Effective (WHOCHOICE). Country-specific unit costs. https:// www.who.int/choice/country/country_ specific/en/ (accessed on 09/Jun/2019).

49. Bryan K. Policies for reducing delayed discharge from hospital. Br Med Bull 2010; 95:33-46.

50. Wallace E, Stuart E, Vaughan N, Bennett K, Fahey T, Smith SM. Risk prediction models to predict emergency hospital admission in community-dwelling adults: a systematic review. Med Care 2014; 52:751-65.

51. Salin S, Kaunonen M, Åstedt-Kurki P. Informal carers of older family members: how they manage and what support they receive from respite care. J Clin Nurs 2009; 18:492-501.

52. Sempé L, Billings J, Lloyd-Sherlock P. Multidisciplinary interventions for reducing the avoidable displacement from home of frail older people: a systematic review. BMJ Open 2019; 9:e030687.

53. Sartini C, Correia M. Programa Maior Cuidado: qualificando e humanizando o cuidado. Pensar BH/Política Social 2012; 31:10-3.

54. Alfradique ME, Bonolo PF, Dourado I, LimaCosta MF, Macinko J, Mendonça CS, et al. Internações por condições sensíveis à atenção primária: a construção da lista brasileira como ferramenta para medir o desempenho do sistema de saúde (Projeto ICSAP - Brasil). Cad Saúde Pública 2009; 25:1337-49.

55. Arrieta A, García-Prado A. Cost sharing and hospitalizations for ambulatory care sensitive conditions. Soc Sci Med 2015; 124:115-20. 


\section{Resumo}

O número crescente de indivíduos muito idosos cria desafios específicos para as politicas de assistência social e de saúde. Os desafios incluem a necessidade de repensar os modelos assistenciais atuais. $\mathrm{O}$ artigo tem como objetivo principal introduzir o conceito de "deslocamento residencial evitável” (DRE). Argumentamos que o conceito de DRE elabora e contribui para os conceitos existentes, oferecendo um arcabouço holístico e centrado na pessoa para a assistência de saúde e social para os idosos. Demonstramos que esse arcabouço pode ser aplicado em diversos níveis, desde a formulação de politicas macro até as decisões organizacionais $e$ individuais. $O$ artigo aborda particularmente o contexto, mas sustenta que o DRE é um conceito universalmente aplicável.

Idoso; Colaboração Intersetorial; Assistência Integral à Saúde; Hospitalização

\section{Resumen}

Un número creciente de personas con edad muy avanzada plantea desafíos específicos para las políticas de salud y atención social. Esto implica la necesidad de repensar los modelos establecidos de provisión de servicios. El objetivo principal de este artículo es introducir el concepto de "desplazamiento evitable del hogar" (DEH). Nosotros planteamos que el DEH se basa y añade valor a conceptos existentes, ofreciendo un marco de trabajo holístico, centrado en la persona para la provisión integrada de salud y atención social a personas mayores. Demostramos que este marco de trabajo se puede aplicar a través de diferentes niveles, que van desde la elaboración de politicas macro a la adopción de decisiones por parte de organizaciones e individuos. Este trabajo fija su atención en particular sobre el contexto brasileño, pero plantea que el DEH es un concepto aplicable universalmente.

Anciano; Colaboración Intersectorial; Atención Integral de Salud; Hospitalización
Submitted on 23/Aug/2019

Final version resubmitted on 26/Dec/2019 Approved on 10/Jan/2020 